\title{
Philippe Andrès, Théodore de Banville, un passeur dans le siècle
}

\section{Ida Merello}

\section{(2) OpenEdition}

1 Journals

\section{Edizione digitale}

URL: http://journals.openedition.org/studifrancesi/7656

DOI: 10.4000/studifrancesi.7656

ISSN: 2421-5856

\section{Editore}

Rosenberg \& Sellier

\section{Edizione cartacea}

Data di pubblicazione: 1 décembre 2009

Paginazione: 653-654

ISSN: 0039-2944

\section{Notizia bibliografica digitale}

Ida Merello, «Philippe Andrès, Théodore de Banville, un passeur dans le siècle», Studi Francesi [Online],

159 (LIII | III) | 2009, online dal 30 novembre 2015, consultato il 09 janvier 2021. URL: http://

journals.openedition.org/studifrancesi/7656 ; DOI: https://doi.org/10.4000/studifrancesi.7656

Questo documento è stato generato automaticamente il 9 janvier 2021.

\section{(c) (i) (9)}

Studi Francesi è distribuita con Licenza Creative Commons Attribuzione - Non commerciale - Non opere derivate 4.0 Internazionale. 


\title{
Philippe Andrès, Théodore de Banville, un passeur dans le siècle
}

\author{
Ida Merello
}

\section{NOTIZIA}

PHILIPPE ANDRÈs, Théodore de Banville, un passeur dans le siècle, Paris, Champion, 2009, pp.

333.

1 La stessa bibliografia situata in fondo all'opera testimonia che questo volume rappresenta il punto di arrivo di un lungo percorso di studioso: sono citati infatti ventisei titoli, tra articoli e monografie, che l'A. ha scritto prima dell'opera in oggetto. Tra gli svariati studi erano già infatti usciti per la Champion nel 1993 un saggio su La Femme et ses métamorphoses dans l'oeuvre de Banville, per L'Harmattan nel 1997 una monografia; inoltre l'A. è stato il curatore delle Idylles prussiennes nell'edizione critica dell'opera poetica sotto la guida di Peter J.Edwards. E la lettura del presente studio lo conferma: il percorso di Banville, sia umano che letterario è esplorato nei minimi dettagli, con disinvolta finezza di erudizione. Il saggio è diviso in capitoli in base a una scansione dettata dagli avvenimenti della vita dell'autore, dall'affermazione delle Cariatides fino alle ultime pièces teatrali della fin de siècle. L'A. ricerca l'esaustività, non certo dal punto di vista di un'analisi approfondita dei testi, che in tale compendio è impossibile, bensì nella minuziosa ricognizione di ogni aspetto della carriera, non solo poetica teatrale o narrativa, ma anche giornalistica e saggistica. Lo scopo dichiarato è infatti quello di presentare attraverso l'insieme della produzione le posizioni ideologiche dello scrittore, sia politiche che religiose, in funzione della storia letteraria, mostrando Banville come "un passeur dans le siècle», erede di Hugo, ma anche «tremplin» verso Rimbaud e la modernità. 